\title{
Úroveň aerobní kapacity elitního dorosteneckého týmu a profesionálního seniorského týmu na začátku př́ípravného období ve fotbale
}

\section{The level of aerobic capacity of elite junior team and senior professional team at the beginning of the preparatory period in soccer}

\author{
Jaroslav Teplan, Tomáš Malý, František Zahálka, Lucia Malá, Aleš Kaplan
}

Fakulta tělesní výchovy a sportu Univerzity Karlovy v Praze

\begin{abstract}
Abstrakt
Cílem této studie bylo zjištěni a porovnáni aktuálního stavu aerobní kapacity mezi profesionálním seniorským týmem a věkově nejstarším elitním dorosteneckým týmem na začátku př́pravného období ve fotbale. Kategorie seniorských hráčủ byla tvořena 17 hráči (věk: 23,5 \pm 3,2 let, tělesná hmotnost: 76,5 \pm 4,2 kg, tělesná výška:

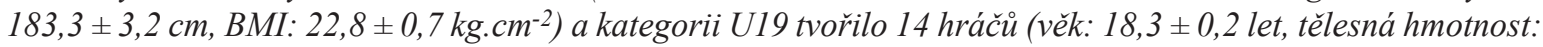

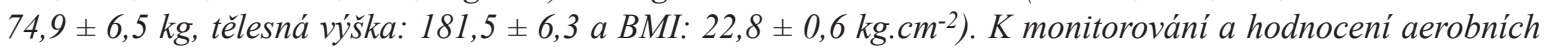
parametrủ byl použit Yo-Yo intermitentní recovery test 1 (Yo-Yo IRT1). Na základě celkové uběhnuté vzdálenosti a parametru VO2max byl výsledek při porovnání rozdilů průměrů sledovaných skupin statisticky významný. Parametry $S F_{\max }$ a pokles $S F$ za 1 minutu nebyly signifikantně významné. Přechod z dorostenecké do seniorské kategorie zvyšuje nároky na rychlost v utkání či provádění individuálních herních činností. Všechny zjištované parametry těchto kategorií jsou pouze predpokladem pro vrcholový výkon v utkání.
\end{abstract}

\begin{abstract}
The aim of this study was to determine and compare the state of aerobic capacity of a men's professional soccer team against the oldest junior elite team at the beginning of practice period. The group of the adult players consisted of 17 players (age: 23,5 $\pm 3,2$ years, body weight: 76,5 $\pm 4,2 \mathrm{~kg}$, height: $183,3 \pm 3,2 \mathrm{~cm}, \mathrm{BMI}$ : $22.8 \pm 0.7 \mathrm{~kg} . \mathrm{m}^{-2}$ ) the Under 19 group consisted of 14 players (age: $18.3 \pm 0.2$ years, body weight: $74.9 \pm 6.5$ $\mathrm{kg}$, height: $181.5 \pm 6.3 \mathrm{~cm}$ and BMI: $\left.22.8 \pm 0.7 \mathrm{~kg} . \mathrm{m}^{-2}\right)$. Monitoring and evaluation of aerobic parameters used the Yo-Yo intermittent recovery test 1 (Yo-Yo IRT1). The difference between the groups was statistically significant when comparing averages of the results based on the overall distance run and parameter $V \mathrm{O}_{2 m a x}$. Differences in parameters $H R_{\max }$ and decrease of $H R$ in a 1 minute were not statistically significant. A transition from a junior category to an adult one puts significant demands on the speed within the game and performance of individual in-game activities. All the surveyed parameters are only a necessary prerequisites for top performance in a match.
\end{abstract}

Kličová slova: Yo-Yo IRT1, fotbal, prípravné obdobi, dorostenecký tým, seniorský tým

Key words: Yo-Yo IRT1, soccer, preparation period, junior team, adult team.

Tento príspěvek vznikl v rámci Výzkumného záměru MŠMT ČR MSM 0021620864, s podporou projektu SVV 2013-267603, GAČR P407/11/P784 a PRVOUK 038.

\section{ÚVOD}

Na začátku přípravného období hráči absolvují diagnostické vyšetření na specializovaných pracovištích (laboratorní) nebo v samotném klubu (terénní), kde se zjišt’uje jejich aktuální stav trénovanost. Na základě výsledků z testování jsou hráčům nastaveny tréninkové plány, př́i kterých se počítá s individualizací zatížení. Pro zvládnutí mistrovského utkání je důležité, aby byl každý hráč funkčně připravený z hlediska aerobního i anaerobního metabolismu. Bloomfield, Polman \& O’Donoghue (2007) dokonce specifikují kondiční požadavky 
na hráče v utkání. Požadavky utkání jsou kladeny především na silové a výbušné činnosti, časté změny směru, zrychlení, zpomalení, rychlosti na různě velké vzdálenosti, rovnováhu, stabilitu těla, flexibilitu a vytrvalost.

Všechny sportovní hry jsou specifické svým herním dějem, zatížením, pohybovým projevem, pravidly a funkcí hráčủ. $Z$ tohoto důvodu je důležité vyhledávat či vytvářet diagnostické testy či baterie, které budou mít výstup pro daný sport.

Pro hodnocení aerobní kapacity ve fotbale je nejpopulárnějším a nejvyužívanějším testem Yo-Yo intermitentní recovery test - úroveň 1 (Yo-Yo IRT1), nebot' odráží základní pohybové činnosti objevující se v utkání (Bangsbo, Iaia \& Krustrup, 2008). Yo-Yo IRT1 odráží pohybové prvky jako je reakce, akcelerace, decelerace popř́padě změna směru a intermitentní zatížení (Teplan, Malý, Zahálka, Hráský, Kaplan \& Malá, 2012). Dủležitost těchto prvků během testování dokazují studie (Bloomfield et al., 2007; Di Salvo \& Pigozzi 1998; Mohr, Krustrup \& Bangsbo, 2003; Reilly 1997), které se zabývaly pohybovým projevem a pohybovými činnostmi hráčů v utkání. Uvedení autoři došli k závěru, že hráč v utkání vykoná kolem 30-40 sprintů různé vzdálenosti, vykoná více než 700 změn směrů a obratů, absolvuje 30-40 výskoků a pádů. Zároveň dodávají, že každý hráčský post vyžaduje rozdílné kondiční a fyziologické nároky, které jsou spjaty či doprovázeny různými energetickými nároky. V utkání se však rovněž vyskytují jiné intenzivní činnosti, které doposud nebyly podrobněji zkoumány, jako je dokončení pohybu hráče, vedení míče či kop do míče (Iaia, Rampinini, \& Bangsbo, 2009).

Během přípravného období dochází k udržení, spíše ke zvyšování kondiční připravenosti, psychické odolnosti, herního systému a individuálních, skupinových či týmových technicko-taktických činností. Hráči musí být neustále stimulováni směrem k utkání. Silva, Santhiago, Papoti \& Gobatto (2008) dodávají, že herní děj v utkání je proměnlivý a hráči by měli být připraveni zvládat a rychle reagovat na měnící se herní situace.

Hráči nastupující v mládežnické kategorii (U19) jsou již po kondiční stránce připravováni stejně jako dospělí hráči tak, aby přechod do jejich kategorie proběhl co nejsnadněji. Reilly, Bangsbo \& Franks (2000) dodávají, že při přechodu mladého hráče do dospělé kategorie je důležité, aby byli schopni se vyrovnat s nároky utkání a tréninkových jednotek.

Proto by se u nich $\mathrm{v}$ prrípravném období měli trenéři více zaměřovat na rozvoj aerobního $\mathrm{i}$ anaerobního metabolismu pomocí herních cvičení a nikoliv neustále stimulovat technicko-taktické činnosti.

Cílem této studie bylo zjištění a následné porovnání aktuálního stavu aerobní kapacity mezi profesionálním týmem dospělých a věkově nejstarším elitním dorosteneckým týmem na začátku přípravného období.

\section{METODIKA}

\section{Charakteristika výzkumného souboru}

Výzkumný soubor byl tvořen profesionálním týmem z druhé fotbalové ligy a elitním týmem staršího dorostu hrajícího I. dorosteneckou ligu. Hráči obou týmů v hlavním období sezóny během týdenního mikrocyklu absolvují 5-6 tréninkových jednotek a mistrovské utkání. Kategorii profesionálního týmu tvořilo 17 hráčủ (věk: 23,5 3,2, tělesná hmotnost: 76,5 $\pm 4,2 \mathrm{~kg}$, tělesná výška: $183,3 \pm 3,2 \mathrm{~cm}$, BMI: $22,8 \pm 0,7 \mathrm{~kg} \cdot \mathrm{cm}^{-2}$ ) a kategorii dorosteneckého týmu tvořilo 14 hráčů (věk: $18.3 \pm 0,2$ let, tělesná hmotnost: $74,9 \pm 6.5 \mathrm{~kg}$, tělesná výška: 181,5 $\pm 6.3 \mathrm{~cm}$, BMI: $22,8 \pm 0,6 \mathrm{~kg} \cdot \mathrm{cm}^{-2}$ ). Brankáŕi do této studie nebyli zahrnuti, nebot' jejich výsledky by výrazně snížily průměrné hodnoty testu. Pro hráče v poli jsou tyto výsledky důležitější než pro brankáře, nebot’u nich tato komponenta primárně nedeterminuje jejich výkon.

Před samotným testováním byli hráči informováni o průběhu a testovacím protokolu.

\section{Metodika získávání a zpracování výzkumných údajů}

Výzkumné údaje byly zjišt'ovány na začátku přípravného období po čtyřtýdenním přechodném období. Samotné testování bylo prováděno na umělé trávě druhé generace. Před testovacím protokolem bylo u obou týmů zajištěno stejné rozcvičení, které se skládalo z rozběhání (5 min), strečinku (4 min), přihrávky s míčem (5 min) a 6 sprintů do vzdálenosti $10 \mathrm{~m}$.

Srdeční frekvence byla hráčům snímána sporttesterem Polar RS400 (Polar, Kempele, Finsko) s 5s intervaly. Všem hráčům byla před zahájením testu zkontrolována funkčnost sporttesterů.

\section{Test aerobni kapacity}

Pro fotbalové utkání je charakteristické intermitentní zatížení. Na tomto základě jsme pro hodnocení aerobní kapacity použili Yo-Yo intermitentní test - úroveň 1 (Yo-Yo IRT1). Yo-Yo IRT1 se skládá z opakovaných 
běžeckých úseků, které jsou vykonávány na předem stanovený signál (pípnutí) přehrávaný z CD přehrávače. Jednotlivé běžecké úseky jsou postupně zrychlovány. Hráči postupně absolvují čtyři úseky v rychlostech 10 - $13 \mathrm{~km} \cdot \mathrm{hod}^{-1}(0-160 \mathrm{~m})$, sedm úseků v rychlostech 13,5 - $14 \mathrm{~km} \cdot \mathrm{hod}^{-1}(160-440 \mathrm{~m})$ následně je rychlost běhu zvyšována o $0,5 \mathrm{~km}$.hod-1 po osmi úsecích (tzn. po 760, 1080, 1400, $1720 \mathrm{~m}$ atd.) až do vyčerpání nebo do nesplnění podmínek testu, kdy testovaný nestihne dvakrát dosáhnout dané vzdálenosti. Maximální vzdálenost, kterou hráč může v průběhu testu absolvovat je 3640 m (Castagna, Impellizzeri, Belardinelli, Abt, Coutts, Chamari \& et al., 2006). Jeden úsek v testu se skládá ze vzdálenosti $2 \times 20 \mathrm{~m}$ (obr. 1), po které následuje 10 sekundový interval aktivního odpočinku v podobě chůze či mírného klusu ve vzdálenosti $2 \times 5 \mathrm{~m}$. Základním ukazatelem trénovanosti je absolvovaná celková vzdálenost (počet úseků). Na základě maximálního úsilí rovněž zjišstujeme maximální srdeční frekvenci (SFmax) a maximální spotřebu kyslíku (VO2max), jenž je přepočítána z predikční rovnice1 (ověřená dle Bangsba et al., 2008) na základě absolvované celkové vzdálenosti. Posledním zjištovaným parametrem byl procentuální pokles SF za jednu minutu po absolvování testu (obr. 2).

$$
1 \operatorname{VO} 2 \max \left(\mathrm{ml} \mathrm{kg}^{-1} \cdot \mathrm{min}^{-1}\right)=\text { vzdálenost }(\mathrm{m}) \times 0,0084+36,4
$$

Při samotném testu bylo mezi sebou testováno paralelně 8 hráčů, kteří měli vytvořen vlastní prostor široký $2 \mathrm{~m}$ a dlouhý $25 \mathrm{~m}$ (20 m pro vykonání testu a $5 \mathrm{~m}$ pro aktivní odpočinek). Na dodržování kvality a správnosti testu dohlíželi 3 examinátoři a 1 zapisovatel.

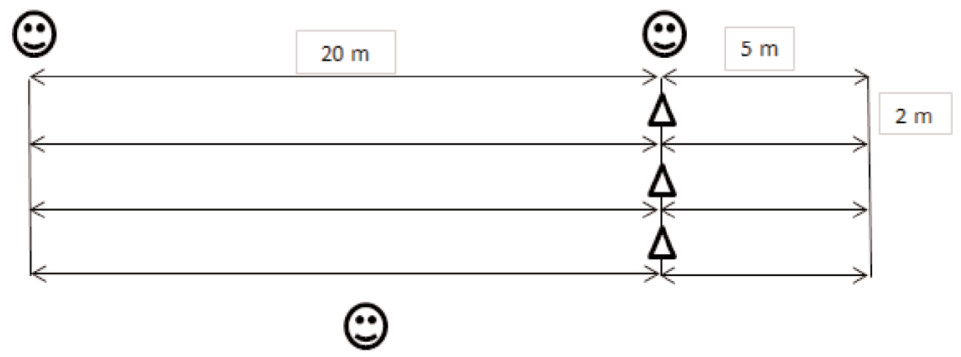

Obr. 1. Znázornění průběhu Yo-Yo IRT1

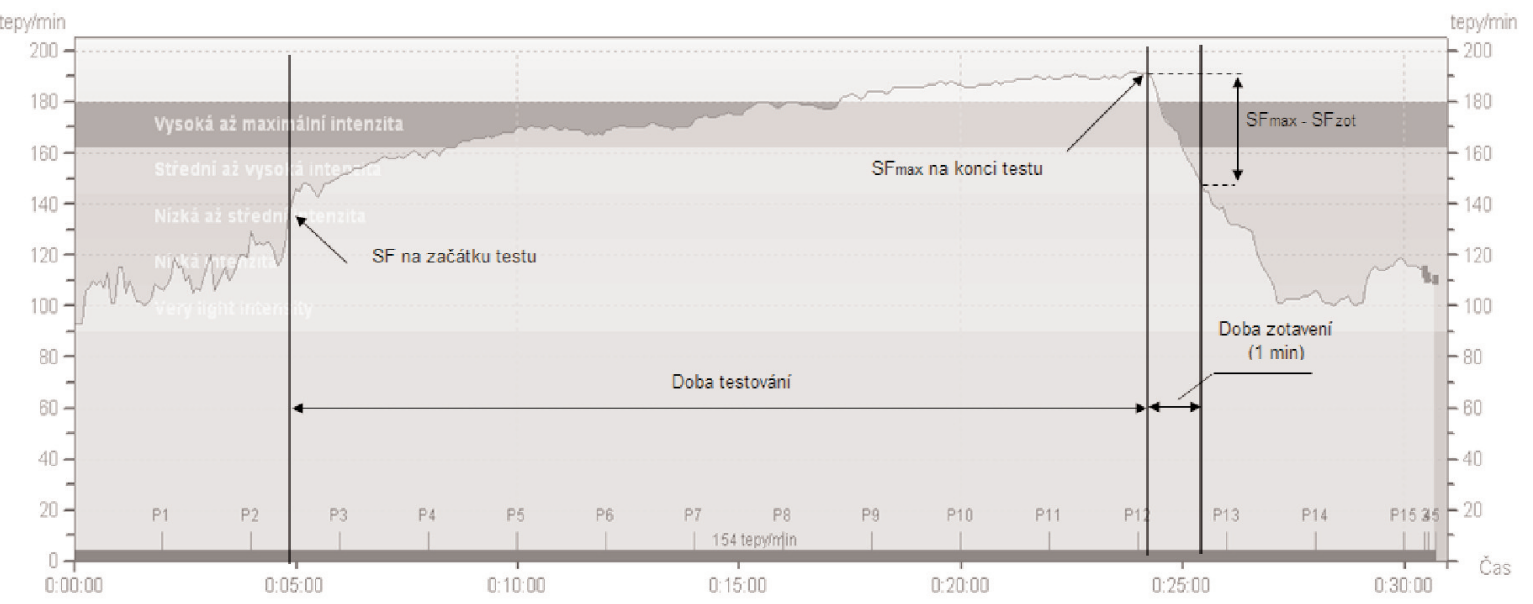

Obr. 2. Znázornění fyziologické křivky testu Yo-Yo IRT1 sporttesterem Polar RS400 (Teplan et al., 2012)

\section{STATISTIKA}

Ke statistickému zpracování výzkumných údajů jsme použili metody deskriptivní a induktivní statistiky. Pro vyjádření míry polohy jsme použili aritmetický průměr a pro vyjádření míry variability směrodatnou odchylku. Rozdíl porovnávaných průměrů u sledovaných parametrů jsme posuzovali pomocí parametrického t-testu pro nezávislé výběry. Shoda rozptylů porovnávaných skupin byla posuzována pomocí Levenova testu. Pro posouzení signifikantního rozdílu mezi průměry porovnávaných skupin jsme zvolili riziko $\mathrm{p}<0,05$. Výsledky jsou prezentované v tabulkovém a grafickém znázornění. Statistika byla zpracována pomocí softwaru SPSS IBM ${ }^{\circledR}$ ver. 20. 


\section{VÝSLEDKY}

Průměrný výsledek v testu Yo-Yo IRT1 u elitních dorostenců představoval 1700 \pm 228 metrů a v kategorii profesionálních seniorských hráčủ $2207 \pm 252$ metrů. Tento rozdíl představuje $23 \%$ a na základě porovnání rozdílů průměrů sledovaných skupin byl statisticky významný (Obr. 3).

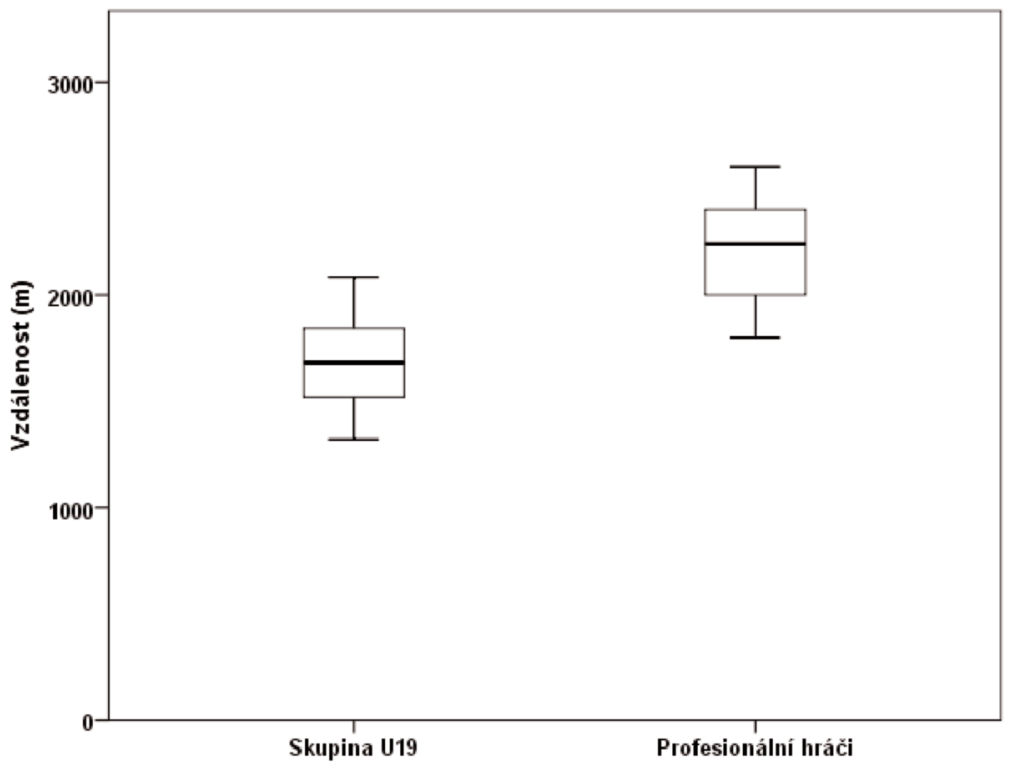

Obr. 3. Znázornění rozdílů průměrů u dorostenců a seniorů

Z hlediska fyziologického zatížení se obě skupiny pohybovaly na úrovni 192 tepy.min-1 a prokázaly taktéž porovnatelnou variabilitu sledovaného parametru. $Z$ metodologického pohledu tak platí tzv. nulová hypotéza o rovnosti rozdílů průměrů porovnávaných skupin $(\mathrm{p}>0,05)$.

Profesionální hráči dosáhli vyšší průměrné hodnoty zotavení $(14,7$ \%) v porovnání s hráči kategorie U19 $(13,5$ \%). Rozdíly v obou porovnávaných skupinách se statisticky nelišily (Tabulka 1).

Tab. 1. Výsledky z Yo-Yo IRT1 mezi profesionálním seniorským týmem a elitním dorosteneckým týmem (U19) na začátku př́pravného období

\begin{tabular}{|c|c|c|c|c|c|c|c|c|c|}
\hline & \multicolumn{2}{|c|}{$\begin{array}{l}\text { Rovnost } \\
\text { rozptylů }\end{array}$} & \multicolumn{7}{|c|}{ t-test pro nezávislé výběry } \\
\hline & \multirow[b]{2}{*}{$\mathrm{F}$} & \multirow[b]{2}{*}{ Sig. } & \multirow[b]{2}{*}{$\mathrm{t}$} & \multirow[b]{2}{*}{ df } & \multirow{2}{*}{$\begin{array}{c}\text { Význam } \\
\text { nost }\end{array}$} & \multirow{2}{*}{$\begin{array}{l}\text { Rozdíl } \\
\text { průměrů }\end{array}$} & \multirow{2}{*}{$\begin{array}{l}\text { Střední } \\
\text { chyba } \\
\text { průměru }\end{array}$} & \multicolumn{2}{|c|}{$\begin{array}{c}\text { 95\% Konfidenční } \\
\text { interval }\end{array}$} \\
\hline & & & & & & & & Spodní & Horní \\
\hline Vzdálenost & ,318 &, 577 & $-5,821$ & 29 &, 000 & $-507,059$ & 87,112 & $-685,223$ & $-328,894$ \\
\hline $\mathrm{SF}_{\max }$ &, 067 & ,798 &,- 071 & 29 & ,944 & $-0,164$ & 2,310 & $-4,888$ & 4,560 \\
\hline Zotaveni &, 004 & ,948 &,- 552 & 29 &, 585 & $-1,218$ & 2,207 & $-5,732$ & 3,297 \\
\hline $\mathrm{VO}_{2 \max }$ & ,322 &, 575 & $-5,820$ & 29 &, 000 & $-4,259$ & 0,732 & $-5,755$ & $-2,762$ \\
\hline
\end{tabular}

Nepř́imo určená hodnota VO2max u dospělých profesionálních hráčů představovala $54,9 \pm 2,1 \mathrm{ml} . \mathrm{kg}$. min-1. U dorostenců byla tato hodnota nižší o $6,9 \%\left(50,7 \pm 1,9 \mathrm{ml} \cdot \mathrm{kg} \cdot \mathrm{min}^{-1}\right)$. Test rozdílů průměrů nezávislých skupin prokázal signifikantní rozdíl v tomto parametru $(\mathrm{p}<0,01)$ (Tabulka 1$)$. 


\section{DISKUSE}

Zjištění funkčního stavu na začátku přípravného období u mladých, ale i seniorských fotbalistů, je důležitým aspektem pro nastavení tréninkového plánu v následujících několika mikrocyklech či mezocyklech. Sofistikované metody diagnostiky individuální připravenosti pro herní výkon mohou vytvořit základ evaluace jednotlivých hráčů a potažmo týmů. Stejně tak lze tímto způsobem porovnávat intraindividuální změny vybraných parametrů každého hráče vzhledem k jednotlivým obdobím sezóny (přípravné období, soutěžní období apod.), nebo porovnání jednotlivých hráčủ a týmů mezi sebou (Teplan, Malý, Hráský, Zahálka, Kaplan, Malá \& et al., 2012). Brink, Nederhof, Visscher, Schmikli \& Lemmink (2010) uvádí, že při pravidelném testování hráčů se zjišs’ují jejich individuální změny v herním výkonu v čase a zároveň dochází $\mathrm{k}$ zabránění aerobního útlumu. Další důvody, proč by měli být hráči testováni, uvádí Bangsbo, Mohr \& Krustrup (2006): sledování vlivu tréninkového programu, motivování hráčů $\mathrm{k}$ většímu úsilí v tréninku, získání zpětné vazby o stavu trénovanosti, schopnost konkurenceschopnosti v týmu či utkání, určení návratu na výkonnostní úroveň během doby rekonvalescence či rekondice, identifikování slabých stránek hráče či k plánování krátkodobého nebo dlouhodobého tréninkového programu.

Tessitore, Meeusen, Cortis \& Capranica (2007) uvedli, že přípravné období je důležité, nebot' po ní následuje dlouhá soutěžní sezóna. V tomto období hráči absovují i několik tréninkových jednotek denně, aby před soutěžní sezónou došlo ke snížení a následnému vylad’ování. Hráči zdokonalují své technicko-taktické dovednosti v únavě. V únavě dochází ke snížení činností, při které je potřeba využívat jemnou motoriku (Teplan et al., 2012).

Výsledky v předkládané studii prokázaly signifikantní rozdíl v uběhnuté vzdálenosti o $23 \%$ ve prospěch seniorského týmu. Tento signifikantní rozdíl mohl být způsoben dynamičností a intenzitou utkání, kde jsou na hráče v seniorské kategorii kladeny vyšší požadavky na výkon a výsledky než u dorosteneckého týmu. Yo-Yo IRT1 je vyznačován vysokou korelací u dospělých fotbalistů $(\mathrm{r}=0,71, \mathrm{p}<0,05)$ (Krustrup, Mohr, Amstrup, Rysgaard, Johansen, Steensberg, Pedersen \& Bangsbo, 2003) a u mladých hráčů $(r=0,77, p<0,001)$ (Castagna, Impellizzeri, Cecchini, Rampinini \& Barbero-Álvarez, 2009). Pomocí tohoto testu, tak můžeme porovnávat aerobní výkonnost i trénovanost seniorských i mládežnických hráčů. V zahraničních studiích není přesně zmiňováno, ve kterém období testování Yo-Yo IRT1 probíhalo a zároveň nebyl porovnáván vzájemný výkon mezi seniorským a dorosteneckým týmem. Spencer, Pyne, Santisteban \& Mujika (2011) testovali elitní dorostenecký tým U18 (n=8), který v průměru uběhl 2715 547 m. V předkládané studii dosáhl elitní dorostenecký tým nižších výsledků o $38 \%$ a profesionální seniorský tým o $17 \%$. Příčinou mohou být odlišné tréninkové metody v zahraničí oproti České republice nebo rozdílné předpoklady pro vykonávání intenzivních činností. U seniorských profesionálních hráčů v zahraničí byla zjištěna průměrná absolvovaná vzdálenost $2420 \mathrm{~m}$ pro mezinárodní úroveň, $2190 \mathrm{~m}$ u ligových týmů a $2030 \mathrm{~m}$ u průměrných hráčů v národních soutěžích (Castagna et al., 2006; Krustrup et al., 2003; Mohr, Krustrup, \& Bangsbo, 2003).

Vypočtená hodnota VO2max z predikční rovnice, která je závislá na celkové absolvované vzdálenosti, je nižší než hodnota VO2max získaná na běžeckém ergometru v laboratorních podmínkách (Bangsbo et al., 2008; Krustrup et al., 2003). Je důležité neustále brát v potaz individuální parametry hráčů jako je věk, tělesná výška či tělesná hmotnost. Reilly, Bangsbo \& Franks (2000) tvrdí, že hráči musí mít dobrou aerobní kapacitu, aby byli schopni odehrát utkání ve vysokém tempu a nasazení. Hodnota $\mathrm{VO}_{2 \max } \mathrm{v}$ této studii byla signifikantně významná ve prospěch seniorského týmu o 6,9\%. U dospělých hráčů sledovali hodnotu $\mathrm{VO}_{2 \max }$ Barbero Alvarez, Barbero-Álvarez \& Granda (2007) a Krustrup et al. (2003). Zjištěné hodnoty byly 55,3 $\pm 1,3 \mathrm{ml}$. $\mathrm{kg}^{-1} \cdot \mathrm{min}^{-1}$ resp. $51,3 \pm 1,1 \mathrm{ml} \cdot \mathrm{kg}^{-1} \cdot \mathrm{min}^{-1}$. U dorosteneckých kategorií sledoval hodnotu $\mathrm{VO}_{2 \max }$ Teplan et al. (2012). U kategorie U16 zjistili hodnotu $\mathrm{VO}_{2 \max }=49,4 \pm 2,7 \mathrm{ml} \cdot \mathrm{kg}^{-1} \cdot \mathrm{min}^{-1}$ a u kategorie U17 $\mathrm{VO}_{2 \max }=52,8 \pm$ $3,2 \mathrm{ml} \cdot \mathrm{kg}^{-1} \cdot \mathrm{min}^{-1}$.

Vzhledem k individualitám závisí SF na maximální kapacitě každého hráče vzhledem k jeho vlastnímu rytmu adaptace a neurovegetativní funkci, jenž zvyšuje či kompenzuje ztráty tekutin, elektrolytů a acidobazické rovnováhy vyskytující se během tréninkové jednotky či utkání (Mishchenko \& Monogarov, 2000). Po ukončení

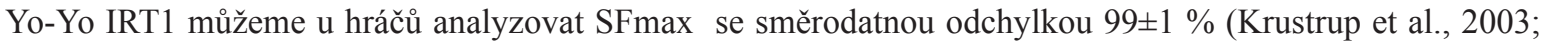
Krustrup et al., 2006). Na základě zjištěné SFmax můžeme každému hráči vypočítat aerobní a anaerobní práh. Ve sledovaném parametru SFmax mezi oběma týmy nebyl zjištěn signifikantní rozdíl (viz Tabulka 1).

Ve fotbalovém utkání se stř́idají období vysoké a nízké intenzity. Bangsbo, Norregaard \& Thorsoe (1991) udávají, že činnosti vysoké intenzity se v utkání opakují každých $3-5 \mathrm{~s}$. Z tohoto důvodu jsme sledovali pokles SFmax za 1 minutu. Rozdíl v poklesu SF mezi oběma týmy nebyl signifikantní (viz Tabulka 1). Sledováním 
poklesu SF můžeme pozorovat trénovanost hráčů a schopnost realizace provádět opakované intenzivní a dynamické činnosti.

\section{ZÁV̌̌R}

Zjištěné parametry aerobní kapacity prokázaly signifikantní rozdíly v celkové uběhnuté vzdálenosti a vyšší hodnoty $\mathrm{VO}_{2 \max }$. Naopak se neprokázaly signifikantní rozdíly v $\mathrm{SF}_{\max }$ a poklesu $\mathrm{SF}$ za 1 minutu.

Můžeme konstatovat, že rozdíl mezi seniorskými profesionálními hráči a elitními dorosteneckými hráči spočívá v intenzitě zatížení. Přechodem z dorostenecké do seniorské kategorie dochází ke zvyšování nároků na rychlost v utkání či provádění individuálních herních činností. Všechny zjišt’ované parametry těchto kategorií jsou pouze předpokladem pro vrcholový výkon $\mathrm{v}$ utkání. Tyto parametry jsou důležitou součástí při nastavování tréninkového plánu.

Diagnostikou během sezóny můžeme hráče neustále monitorovat a zaroveň posouvat jejich trénovanost. V rámci diagnostiky nemusíme sledovat pouze výkonnostní hledisko, ale i hledisko zdravotní. Na základě poznatků a výsledků v této studii považujeme celkovou diagnostiku za prínos pro trenéry a jejich hráče.

\section{LITERATURA}

Bangsbo, J., Iaia, F. \& Krustrup, P. (2008). The yo- yo intermittent recovery test: A useful tool for evaluation of physical performance in intermittent sports. Sports of Medicine, 38, $37-51$.

Bangsbo, J., Mohr, M. \& Krustrup, P. (2006). Physical and metabolic demands of training and match-play in the elite football player. Journal of Sports Sciences, 24, $665-674$.

Bangsbo, J., Norregaard, L. \& Thorsoe, F. (1991). Activity profile of competition soccer. Canadian Journal of Applied Sports Sciences, 16, $110-116$.

Barbero-Álvarez, J.C., Barbero-Álvarez, V. \& Granda, J. (2007). Perfil de actividad durante el juego en futbolistas infantiles. Apunts. Educación Física y deportes, 90, 33-41.

Bloomfield, J., Polman, R. \& O’Donoghue, P. (2007). Physical demands of different positions in FA Premier League soccer. Journal of Sports Science and Medicine, 6, 63 - 70.

Brink, M. S., Nederhof, E., Visscher, C., Schmikli, L. \& Lemmink, K. A. M. P. (2010). Monitoring load, recovery, and performance in young elite soccer players. Journal of Strength and Conditioning Research, 24, 597-603. Castagna, C., Impellizzeri, F.M., Belardinelli, R., Abt, G., Coutts, A., Chamari, K. \& et al. (2006). Cardiorespiratory responses to Yo-Yo Intermittent Endurance Test in nonelite youth soccer players. Journal of Strength and Conditioning Research, 26, 326-330.

Castagna, C., Impellizzeri, F. M., Cecchini, E., Rampinini, E. \& Barbero-Álvarez, C. J. (2009). Effects of intermittent-endurance fitness on match performance in young male soccer players. Journal of Strength and Conditioning Research, 23, 1954-1959.

Di Salvo, V.\& Pigozzi, F. (1998). Physical training of football players based on their positional roles in the team. Journal of Sports Medicine and Physical Fitness, 38, 294-297.

Iaia, M. I., Rampinini, E., \& Bangsbo, J. (2009). High-intensity training in football. International Journal of Sports Physiology and Performance, 4, 291 - 306.

Krustrup, P., Mohr, M., Amstrup, T., Rysgaard, T., Johansen, J., Steensberg, A., Pedersen, P.K. \& Bangsbo, J. (2003). The yo-yo intermittent recovery test: Physiological response, reliability and validity. Medicine and Science in Sport and Exercise, 35, 697 - 705.

Krustrup, P., Mohr, M., Steensberg, A., Bencke, J, Kjaer, M. \& Bangsbo, J. (2006). Muscle and blood metabolities during a soccer game: implications for sprint performance. Medicine and Science in Sports and Exercise, $38,1-10$.

Mishchenko, V. S. \& Monogarov, V. D. (2000). Fisiología del deportista. Ed Paidotribo, V, 171-216.

Mohr, M., Krustrup, P. \& Bangsbo, J. (2003). Match performance of high - standard soccer players with special reference to development of fatigue. Journal of Sports Sciences, 21, $519-528$.

Reilly, T. (1997). Energetics of high-intensity exercise (soccer) with particular reference to fatigue. Journal of Sports Sciences, 15, 143-144.

Reilly, T., Bangsbo, J. \& Franks, A. (2000) Anthropometric and physiological predispositions in soccer. Journal of Sport Sciences, 18, 669-683. 
Silva, A.S.R., Santhiago, V., Papoti, M. \& Gobatto, C.A. (2008). Hematological parameters and anaerobic threshold in Brazilian soccer players throughout a training program. International Journal of Laboratory Hematology, 30, 158-166.

Spencer, M., Pyne, D., Santisteban, J. \& Mujika, I. (2011). Fitness determinants of repeated-sprint ability in highly trained youth football players. International Journal of Sports Physiology and Performance, 6, 497-508.

Teplan, J., Malý, T., Zahálka, F., Hráský, P., Kaplan, A. \& Malá, L. (2012). Level of an aerobic capacity of soccer U17 category teams with different succes. Studia Kinanthropologica, 13, 37-44.

Teplan, J., Malý, T., Hráský, P., Zahálka, F., Kaplan, A., Malá, L. \& et al. (2012). Funkční charakteristiky hráčů fotbalu. Studia Sportiva, 6, 69-82.

Tessitore, A., Meeusen, R., Cortis, C. \& Capranica, L. (2007). Effects of different recovery interventions on anaerobic performance following preseason soccer training. Journal of Strength and Conditioning Research, $21,745-750$. 